\title{
THE ASIAN WORKFORCE IN \\ NEW ZEALAND'S ECONOMY
}

\author{
Juthika Badkar ${ }^{1}$ \\ Department of Labour
}

Carmel Tuya

Department of Labour

\begin{abstract}
Significant changes in the composition of New Zealand's population over the last two decades have resulted in greater ethnic diversity in New Zealand, especially in our workforce. These changes have several labour market implications such as changing attitudes, values and approach to work. The 2006 Census showed that Asians comprised the fourth largest major group of ethnicities in New Zealand, comprising 9.2 percent of our population. This proportion is expected to increase to approximately 15 percent by 2026 - which will almost equal the Maori workforce.

As it is important to understand and improve the performance of New Zealand's labour market, the Department of Labour has recently released a report, The Asian Workforce: a critical part of New Zealand's current and future labour market, which examines the characteristics of the Asian workforce in New Zealand. ${ }^{2}$ This looks at their qualifications and skills; and the distinct areas of the labour market they occupy. This report also makes an attempt to disaggregate the collective term 'Asian' into four sub-groups: North Asian, Southeast Asian, South Asian and Other Asian in order to provide a better understanding of each of these diverse subgroups.

Asians are a growing part of the New Zealand population. Understanding their contribution to the future workforce and the skills they will bring will help support the government's economic growth agenda, by ensuring New Zealand has the skills it needs.
\end{abstract}

${ }^{1}$ Correspondence to: Juthika.Badkar@dol.govt.nz

${ }^{2}$ http://www.dol.govt.nz/services/LMI/workforce2020/asian-workforce/ 


\section{Introduction}

Growing Asian population in NZ

In the 2006 Census, the Asian ethnic group comprised 9.2 percent of the total New Zealand population and was the fourth largest group after European, Māori and Other Ethnicity ${ }^{1}$.

The Asian population is substantial and is growing fast Figure 1 demonstrates the extent of this, where New Zealand's Asian population has more than trebled from around 100,000 in 1991 to over 350,000 in 2006.

\section{Figure 1: Growth in New Zealand's Asian population} $1991-2006^{2}$

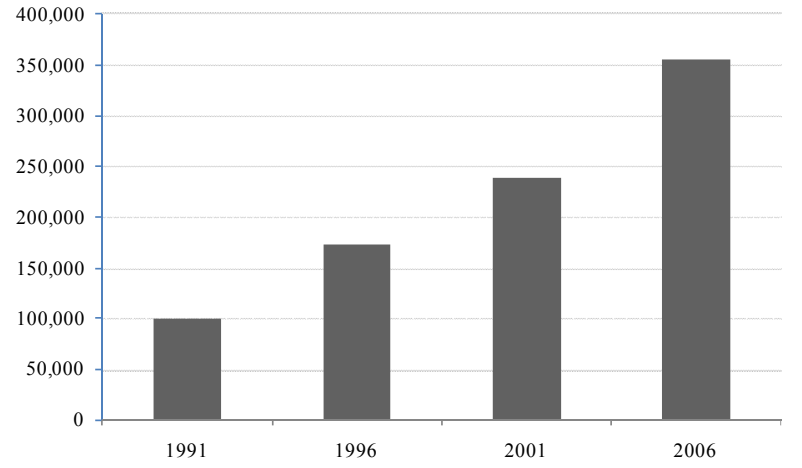

Source: Census of Population and Dwellings 1991-2006, Statistics New Zealand.

People of Asian ethnicities have been living in New Zealand since the nineteenth century. In the mid-1980's and 1990's the Asian population in New Zealand grew rapidly due to the 1986 Immigration Policy Review. This change in migration policy led to a growth in the number of skilled Asians entering highly skilled occupations in New Zealand in areas where there have been labour shortages, especially in the health, business and information technology sectors.

\section{Growing Asian workforce in NZ}

The Asian workforce ${ }^{3}$ has grown since 1996, where they made up five percent of the total workforce, rising to seven percent in 2001 and nine percent in 2006.

Future growth of the Asian population in $N Z$

Figure 2 shows that the Asian workforce in New Zealand is projected to make up 13 percent of the total workforce in 2016 to 15 percent in 2026, which will almost equal the share of the Māori workforce (14 percent), demonstrating that Asians are a critical part of New Zealand's current and future labour market.
Figure 2: Asian working-age population as a share of the total New Zealand working-age population 1996-2006

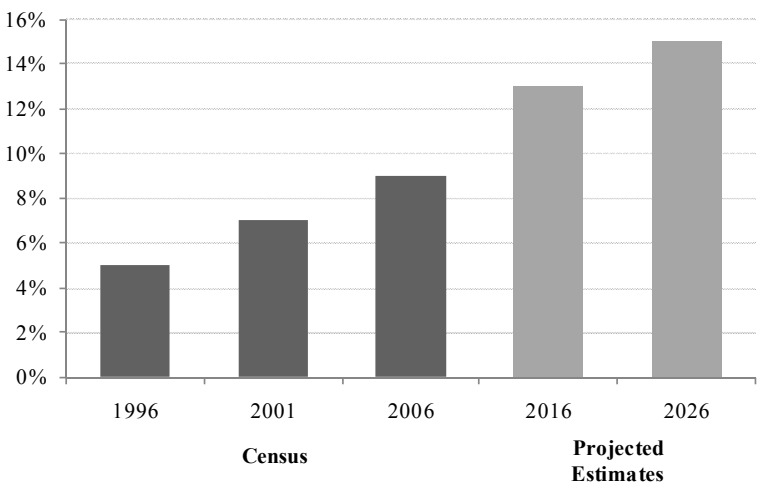

Sources: Census of Population and Dwellings 1996-2006 and National Population Projections: 2006(base)-2026, Statistics New Zealand

\section{Methodology}

The datasets used in this analysis are from the 1996, 2001 and 2006 Censuses of Population and Dwellings. The findings in this paper relate to the population that identify those with Asian ethnicities. The analysis is mainly descriptive and focuses on those in the working-age population.

Given the diversity within Asians in New Zealand and to minimise the impact of averaging, the Asian ethnic group is stratified into four main subgroups by geographic region: North Asian, Southeast Asian, South Asian and Other Asian. The definition used in this report is based on Statistics New Zealand's definition of Asia which excludes people originating from the Middle East and Asian Russia. ${ }^{4}$

\section{Results}

The results presented in this paper are drawn from the recent Department of Labour report, The Asian Workforce: a critical part of New Zealand's current and future labour market. The data reported in this paper are mainly based on the 2006 Census of Population and Dwellings.

\section{Key findings}

Majority were born overseas

Table 1 show that a significant proportion (91 percent) of the Asian workforce was born overseas. It is worth noting that this would include those who came to New Zealand as children and are likely to be educated and trained in New Zealand.

Table 1: Proportion of the working-age population of Asian ethnicity who were born in New Zealand and overseas, 2006

\begin{tabular}{|l|c|c|}
\hline Birthplace & $\begin{array}{c}\text { Asian } \\
\text { workforce }\end{array}$ & $\begin{array}{c}\text { New Zealand } \\
\text { workforce }\end{array}$ \\
\hline NZ-born & $9 \%$ & $74 \%$ \\
Overseas-born & $91 \%$ & $26 \%$ \\
\hline
\end{tabular}


Total (N)

$\mathbf{2 7 5 , 4 1 8}$

$\mathbf{2 , 9 8 8 , 8 1 3}$

Source: Census of Population and Dwellings 2006, Statistics

New Zealand.

\section{Youthful workforce}

The Asian workforce is youthful. Table 2 shows that half of the Asian working-age population were aged between 15-34 years compared to just over a third ( 35 percent) of the national average. The youthfulness of the Asian population can be attributed to three factors: 1 . the presence of Asian international students; 2. the children of Asian immigrants in the mid-80's; and 3. overall migrants being young due to immigration policy's age selective criteria.

Table 2: Proportion of the working-age population of Asian ethnicity by age group, 2006

\begin{tabular}{|l|c|c|}
\hline Age Group & $\begin{array}{c}\text { Asian } \\
\text { workforce }\end{array}$ & $\begin{array}{c}\text { New Zealand } \\
\text { workforce }\end{array}$ \\
\hline 15-34 years & $50 \%$ & $35 \%$ \\
$35-54$ years & $37 \%$ & $37 \%$ \\
55 years \& over & $13 \%$ & $29 \%$ \\
Total (N) & $\mathbf{2 7 5 , 4 1 8}$ & $\mathbf{2 , 9 8 8 , 8 1 3}$ \\
\hline
\end{tabular}

Source: Census of Population and Dwellings 2006, Statistics New Zealand.

\section{Highly qualified workforce}

The Asian workforce is highly qualified and skilled due to New Zealand's immigration policy which is focused on attracting skilled migrants to meet the labour demand in areas of skill shortages. Asians are more likely to hold a bachelor's degree or higher, especially in the younger age cohorts $^{5}$ (see Table 3).

Table 3: Proportion of the working-age population of Asian ethnicity by highest qualification, 2006

\begin{tabular}{|l|c|c|}
\hline Highest qualification & $\begin{array}{c}\text { Asian } \\
\text { workforce }\end{array}$ & $\begin{array}{c}\text { New } \\
\text { Zealand } \\
\text { workforce }\end{array}$ \\
\hline $\begin{array}{l}\text { Overseas secondary school } \\
\text { qualification }\end{array}$ & $25 \%$ & $6 \%$ \\
$\begin{array}{l}\text { Level 1-4 certificate to Level } \\
\text { 5-6 diploma }\end{array}$ & $34 \%$ & $53 \%$ \\
$\begin{array}{l}\text { Bachelor's degree and Level } \\
7 \text { qualification }\end{array}$ & $21 \%$ & $11 \%$ \\
$\begin{array}{l}\text { Post-grad, honours, masters } \\
\text { \& Doctorate degree }\end{array}$ & $8 \%$ & $5 \%$ \\
No qualification & $12 \%$ & $25 \%$ \\
Total (N) & $\mathbf{2 5 9 , 0 4 1}$ & $\mathbf{2 , 8 1 5 , 3 5 6}$ \\
\hline
\end{tabular}

Source: Census of Population and Dwellings 2006, Statistics New Zealand.

\section{Unemployment rate}

Figure 3 shows the unemployment rate of Asians compared to European, Māori and Pacific ethnicities. Unemployment has increased in the last two years across all ethnicities. Although the unemployment rate for Asians has doubled (10.5 percent) since the 2006 Census (5.3 percent), Asians have a lower unemployment rate compared to Māori and Pacific ethnicities. This could be attributed to Asians being highly skilled, and the demand for skilled occupations continues despite the economic downturn. Although there was a drop in employment in New Zealand due to the recession, the largest absolute growth in total employment demand was at the highly skilled level (Manning, R. and SriRamaratnam, R.). China and the Philippines were the third and fourth largest source country of skilled migrants of skilled migrants (source country of skilled migrant category) (Department of Labour, 2009).

Figure 3: Unemployment rate by ethnicity June 2008 - June 2010 quarter

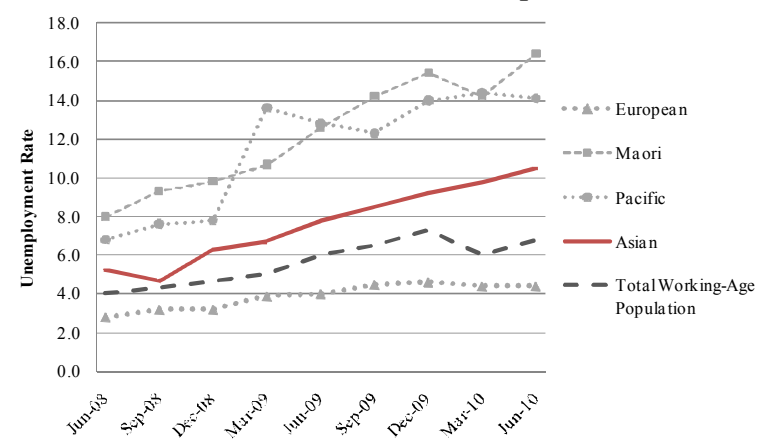

Source: Household and Labour Force Survey (HLFS) June 2008-June 2010 quarters, Statistics New Zealand

\section{Industry}

The Asian workforce was over-represented in the following sectors: retail trade; accommodation, cafes and restaurants; and property and business services (see Table A1).

In the retail trade sector, 22 percent of Asians were working in this sector compared to 13 percent of the total New Zealand workforce. The high representation of Asians in the retail trade sector can be attributed to the entrepreneurial nature of many Asian people where 26 percent working in this industry were self-employed, which was markedly higher than the national average of 18 percent. In addition, 5 percent of Asians in this industry were employed as unpaid family workers compared to the national average of 2 percent ${ }^{6}$.

Other than their entrepreneurial nature, Asians are inclined to work in the retail trade sector due to it being relatively easy to enter as there are no obvious barriers in terms of qualification recognition, language and New Zealand work experience. Being self-employed removes many of the barriers Asian migrants face when seeking jobs from employers.

Although the proportion of Asians in the retail trade sector is higher compared to the national average, this is also high across all Asian subgroups.

\section{Occupation}


The Asian workforce was over-represented in the following occupations: Professionals and Service and Sales Workers (see Table A2).

Eighteen percent of Asians were employed as professionals compared to the national average of 16 percent. The high representation of Asians in this occupation is a reflection of Asia being an important source of skilled migrants.

Within the professional occupation group, 24 percent of Asians were employed as business professionals, followed by 16 percent as computing professionals and 11 percent as health professionals, where their share is considerably higher than the national average (see Table A3).

A fifth (20 percent) of the Asian workforce was employed as service and sales workers compared to 14 percent of the national average. This proportion is also high across all Asian subgroups.

Within the service and sales workers occupation group, 45 percent of Asians were employed as housekeeping and restaurant workers. This can be attributed to the entrepreneurial nature of many Asians who own their own restaurants. In addition to this, the youthfulness of the Asian population could be a contributing factor as these occupations are more likely to attract younger people due to the minimal entry requirements in terms of qualifications, New Zealand work experience and for some, English language proficiency.

\section{Specific Findings by Asian subgroup}

The Asian workforce is not homogenous. New Zealand and overseas-born Asians from different parts of Asia occupy distinct parts of New Zealand's labour market.

\section{North Asians}

A third ( 32 percent) of North Asians were aged between 15-24 years. The presence of international students coming particularly from Korea and China would account for the higher proportion of North Asians in this age group compared to other Asian subgroups.

More than half (52 percent) of North Asians in service and sales occupations (a low skilled occupation group) were employed as housekeeping and restaurant workers. This was almost double the national average of 27 percent. The presence of international students and growth in 'ethnic' restaurants from this region would explain the high proportion for this group.

Almost a fifth (18 percent) of North Asians in professional occupations (a highly skilled occupation group) were employed as Computing professionals. This reflects the growth in the information technology sector and the demand for highly skilled immigrants to work in this sector. (See Table A3)

\section{Southeast Asians}

In highly skilled jobs, almost a third (28\%) of Southeast Asians in professional occupations were employed as Nursing and Midwifery professionals. This was more than double of the national average of 12 percent. Nurses particularly from the Philippines would account for this high proportion. (See Table A3)

Historically most nurses and midwives have been female and this trend continues. Nurses from most areas of Asia follow this pattern; however this is an exception for Southeast Asians where the proportion of male nurses (15 percent) is considerably higher compared to the other Asian subgroups and the national average ( 7 percent), which suggests that Southeast Asian men train as nurses as it offers an opportunity to migrate and work overseas (given the growing global demand).

Migrant nurses from Southeast Asia are of increasing importance in meeting the labour shortages in this area. This reflects the growth in the demand for nurses in New Zealand (Badkar et al 2007; Badkar, Callister \& Didham 2008).

Compared to other Asian subgroups, 57 percent of Southeast Asians were employed in semiskilled/elementary occupations. This could be due to the youthfulness of the population (27 percent were aged 1524 years) and the high proportion (48 percent) of Southeast Asians working as housekeeping and restaurant services workers (second largest after North Asians).

\section{South Asians}

South Asians were highly qualified where a third (33 percent) had a bachelor's degree or higher compared to 16 percent of the national average. This reflects the growth in skilled immigrants coming from this region, especially from India (Department of Labour 2009).

In highly skilled jobs, South Asians in professional occupations were two times more likely to be employed as health professionals than the national average (12 percent versus 6 percent), reflecting the growing demand for medical professionals in New Zealand. After North Asians, South Asians are also more likely to be employed as computing professionals, compared to the national average (15 percent versus $10 \%)$.

\section{Discussion}

New Zealand's future workforce will become more diverse. The Asian population is growing at a rate higher than any other ethnic group in New Zealand. In 2026 the Asian workforce is projected to comprise 15 percent of the working-age population (which will almost equal the Māori workforce), forming a critical and skilled part of New Zealand's labour market, and by adding to the diversity in our workplaces.

Net migration and natural increase are the two main factors that will drive growth in the Asian population. In the future the Asian population will remain younger compared to the overall New Zealand population due to the presence of international students, growth in the 
number of New Zealand-born Asians and immigration's age-selective policies. A great majority of Asians will still be immigrants but the share of the New Zealand-born Asian workforce will grow. In the future, second generation Asians might not face the same barriers being born and bred New Zealanders, educated and trained here, and for many English would be their first language.

\section{Future Opportunities}

Future employers need to recognise the value of diversity in their workplaces. They need to be agile to respond and capitalise on this future change. Asians will be an important source of skilled labour and employers need to ensure that their existing skills and links with Asia are maximised and harnessed, and that they are given choices and opportunities to contribute to New Zealand's workforce.

${ }^{1}$ The Other ethnicity group includes the New Zealander response and Other ethnicity.

${ }^{2}$ Prior to the 1991 Census, Asians were classified under Other ethnicity.

${ }^{3}$ The Asian workforce (also known as the working-age population) comprises those aged 15 years and over.

${ }^{4}$ Badkar, J. and Tuya, C., 2010, Table 4, p19.

${ }^{5}$ Badkar, J. and Tuya, C., 2010, Table A5, p47.

${ }^{6}$ Badkar, J. and Tuya, C., 2010, Table 12, p32

\section{Appendix}

Table A1: Proportion of the employed working-age population by industry groups, 2006

\begin{tabular}{|c|c|c|c|c|c|c|}
\hline \multirow[b]{2}{*}{ Industry } & \multicolumn{4}{|c|}{ Ethnicity } & \multirow[b]{2}{*}{$\begin{array}{l}\text { Total } \\
\text { Asian }\end{array}$} & \multirow{2}{*}{$\begin{array}{c}\text { Total } \\
\text { employed } \\
\text { in NZ }\end{array}$} \\
\hline & $\begin{array}{l}\text { North } \\
\text { Asian }\end{array}$ & $\begin{array}{c}\text { Southeast } \\
\text { Asian }\end{array}$ & $\begin{array}{c}\text { South } \\
\text { Asian }\end{array}$ & $\begin{array}{l}\text { Other } \\
\text { Asian }\end{array}$ & & \\
\hline Agriculture, Forestry and Fishing & $2 \%$ & $3 \%$ & $3 \%$ & $3 \%$ & $3 \%$ & $7 \%$ \\
\hline Mining & $0 \%$ & $0 \%$ & $0 \%$ & $0 \%$ & $0 \%$ & $0 \%$ \\
\hline Manufacturing & $9 \%$ & $18 \%$ & $11 \%$ & $14 \%$ & $11 \%$ & $12 \%$ \\
\hline Electricity, Gas and Water Supply & $0 \%$ & $0 \%$ & $0 \%$ & $0 \%$ & $0 \%$ & $0 \%$ \\
\hline Construction & $3 \%$ & $4 \%$ & $3 \%$ & $4 \%$ & $3 \%$ & $8 \%$ \\
\hline Wholesale Trade & $6 \%$ & $5 \%$ & $6 \%$ & $5 \%$ & $6 \%$ & $6 \%$ \\
\hline Retail Trade & $23 \%$ & $18 \%$ & $21 \%$ & $14 \%$ & $22 \%$ & $13 \%$ \\
\hline Accommodation, Cafes and Restaurants & $12 \%$ & $12 \%$ & $6 \%$ & $8 \%$ & $10 \%$ & $5 \%$ \\
\hline Transport and Storage & $4 \%$ & $2 \%$ & $5 \%$ & $3 \%$ & $4 \%$ & $4 \%$ \\
\hline Communication Services & $1 \%$ & $1 \%$ & $2 \%$ & $2 \%$ & $2 \%$ & $1 \%$ \\
\hline Finance and Insurance & $4 \%$ & $4 \%$ & $6 \%$ & $5 \%$ & $5 \%$ & $3 \%$ \\
\hline Property and Business Services & $16 \%$ & $12 \%$ & $14 \%$ & $15 \%$ & $15 \%$ & $14 \%$ \\
\hline Government Administration \& Defence & $2 \%$ & $3 \%$ & $3 \%$ & $4 \%$ & $3 \%$ & $4 \%$ \\
\hline Education & $6 \%$ & $4 \%$ & $6 \%$ & $6 \%$ & $5 \%$ & $7 \%$ \\
\hline Health and Community Services & $6 \%$ & $10 \%$ & $10 \%$ & $11 \%$ & $8 \%$ & $9 \%$ \\
\hline Cultural and Recreational Services & $2 \%$ & $2 \%$ & $2 \%$ & $3 \%$ & $2 \%$ & $3 \%$ \\
\hline Personal and Other Services & $4 \%$ & $2 \%$ & $2 \%$ & $2 \%$ & $3 \%$ & $4 \%$ \\
\hline Total & 68,880 & 20,454 & 56,586 & 1,593 & 146,235 & $1,864,608$ \\
\hline
\end{tabular}

Source: Census of Population and Dwellings 2006, Statistics New Zealand.

Table A2: Proportion of the employed working-age population by occupation groups, 2006

\begin{tabular}{|c|c|c|c|c|c|c|}
\hline \multirow[b]{2}{*}{ Occupation } & \multicolumn{4}{|c|}{ Ethnicity } & \multirow{2}{*}{$\begin{array}{l}\text { Total } \\
\text { Asian }\end{array}$} & \multirow{2}{*}{$\begin{array}{c}\text { Total } \\
\text { employed } \\
\text { in NZ }\end{array}$} \\
\hline & $\begin{array}{l}\text { North } \\
\text { Asian }\end{array}$ & $\begin{array}{c}\text { Southeast } \\
\text { Asian }\end{array}$ & $\begin{array}{l}\text { South } \\
\text { Asian }\end{array}$ & $\begin{array}{l}\text { Other } \\
\text { Asian }\end{array}$ & & \\
\hline Legislators, Administrators and Managers & $17 \%$ & $9 \%$ & $15 \%$ & $12 \%$ & $15 \%$ & $15 \%$ \\
\hline Professionals & $17 \%$ & $15 \%$ & $20 \%$ & $18 \%$ & $18 \%$ & $16 \%$ \\
\hline Technicians and Associate Professionals & $12 \%$ & $11 \%$ & $14 \%$ & $13 \%$ & $13 \%$ & $13 \%$ \\
\hline Trades Workers & $5 \%$ & $8 \%$ & $6 \%$ & $6 \%$ & $6 \%$ & $9 \%$ \\
\hline Clerks & $12 \%$ & $13 \%$ & $15 \%$ & $15 \%$ & $13 \%$ & $12 \%$ \\
\hline Service and Sales Workers & $23 \%$ & $22 \%$ & $16 \%$ & $18 \%$ & $20 \%$ & $14 \%$ \\
\hline Agriculture and Fishery Workers & $2 \%$ & $2 \%$ & $3 \%$ & $2 \%$ & $2 \%$ & $7 \%$ \\
\hline Plant and Machine Operators and Assemblers & $5 \%$ & $11 \%$ & $8 \%$ & $8 \%$ & $7 \%$ & $8 \%$ \\
\hline Labourers and Related Elementary Service Workers & $7 \%$ & $9 \%$ & $6 \%$ & $7 \%$ & $7 \%$ & $7 \%$ \\
\hline Total & 68,715 & 20,406 & 56,292 & $\mathbf{1 , 5 9 0}$ & 145,731 & $1,862,823$ \\
\hline
\end{tabular}

Source: Census of Population and Dwellings 2006, Statistics New Zealand

Table A3: Proportion of the employed working-age population for Professionals and Service and Sales Workers by Asian ethnicity and total population, 2006 


\begin{tabular}{|c|c|c|c|c|c|c|}
\hline \multirow[b]{2}{*}{ Occupation } & \multicolumn{4}{|c|}{ Ethnicity } & \multirow[b]{2}{*}{$\begin{array}{l}\text { Total } \\
\text { Asian }\end{array}$} & \multirow{2}{*}{$\begin{array}{c}\text { Total } \\
\text { employed } \\
\text { in NZ }\end{array}$} \\
\hline & $\begin{array}{l}\text { North } \\
\text { Asian }\end{array}$ & $\begin{array}{l}\text { Southeast } \\
\text { Asian }\end{array}$ & $\begin{array}{l}\text { South } \\
\text { Asian }\end{array}$ & $\begin{array}{l}\text { Other } \\
\text { Asian }\end{array}$ & & \\
\hline $\begin{array}{l}211 \text { Physicists, Chemists and Related Professionals } \\
212 \text { Mathematicians, Statisticians and Related }\end{array}$ & $0 \%$ & $1 \%$ & $1 \%$ & $0 \%$ & $1 \%$ & $1 \%$ \\
\hline Professionals & $1 \%$ & $0 \%$ & $0 \%$ & $0 \%$ & $0 \%$ & $0 \%$ \\
\hline 213 Computing Professionals & $18 \%$ & $14 \%$ & $15 \%$ & $13 \%$ & $16 \%$ & $10 \%$ \\
\hline 214 Architects, Engineers and Related Professionals & $9 \%$ & $8 \%$ & $8 \%$ & $9 \%$ & $8 \%$ & $9 \%$ \\
\hline 221 Life Science Professionals & $2 \%$ & $1 \%$ & $2 \%$ & $2 \%$ & $2 \%$ & $2 \%$ \\
\hline 222 Health Professionals (except Nursing) & $10 \%$ & $7 \%$ & $12 \%$ & $7 \%$ & $11 \%$ & $6 \%$ \\
\hline 223 Nursing and Midwifery Professionals & $5 \%$ & $28 \%$ & $11 \%$ & $22 \%$ & $10 \%$ & $12 \%$ \\
\hline 231 Tertiary Teaching Professionals & $6 \%$ & $4 \%$ & $5 \%$ & $8 \%$ & $5 \%$ & $6 \%$ \\
\hline $\begin{array}{l}232 \text { Secondary Teaching Professionals } \\
233 \text { Primary and Early Childhood Teaching }\end{array}$ & $4 \%$ & $2 \%$ & $6 \%$ & $6 \%$ & $4 \%$ & $7 \%$ \\
\hline Professionals & $5 \%$ & $6 \%$ & $11 \%$ & $5 \%$ & $8 \%$ & $15 \%$ \\
\hline 234 Special Education Teaching Professionals & $2 \%$ & $1 \%$ & $1 \%$ & $1 \%$ & $1 \%$ & $2 \%$ \\
\hline 235 Other Teaching Professionals & $1 \%$ & $0 \%$ & $0 \%$ & $0 \%$ & $1 \%$ & $1 \%$ \\
\hline 241 Business Professionals & $27 \%$ & $21 \%$ & $23 \%$ & $18 \%$ & $24 \%$ & $18 \%$ \\
\hline $\begin{array}{l}242 \text { Legal Professionals } \\
243 \text { Archivists, Librarians and Related Information }\end{array}$ & $3 \%$ & $2 \%$ & $2 \%$ & $1 \%$ & $2 \%$ & $4 \%$ \\
\hline Professionals & $1 \%$ & $1 \%$ & $1 \%$ & $2 \%$ & $1 \%$ & $2 \%$ \\
\hline 244 Social and Related Science Professionals & $5 \%$ & $3 \%$ & $2 \%$ & $5 \%$ & $3 \%$ & $4 \%$ \\
\hline 245 Religious Professionals & $2 \%$ & $1 \%$ & $1 \%$ & $1 \%$ & $1 \%$ & $1 \%$ \\
\hline 2 Professionals & 11,565 & 2,976 & 10,980 & 300 & 25,569 & 290,784 \\
\hline 511 Travel Attendants and Guides & $4 \%$ & $1 \%$ & $1 \%$ & $1 \%$ & $2 \%$ & $2 \%$ \\
\hline 512 Housekeeping and Restaurant Services Workers & $52 \%$ & $48 \%$ & $30 \%$ & $39 \%$ & $45 \%$ & $27 \%$ \\
\hline 513 Personal Care Workers & $5 \%$ & $13 \%$ & $14 \%$ & $11 \%$ & $9 \%$ & $15 \%$ \\
\hline 514 Other Personal Services Workers & $5 \%$ & $6 \%$ & $4 \%$ & $5 \%$ & $5 \%$ & $8 \%$ \\
\hline 515 Protective Services Workers & $1 \%$ & $2 \%$ & $5 \%$ & $6 \%$ & $3 \%$ & $10 \%$ \\
\hline 521 Salespersons and Demonstrators & $32 \%$ & $30 \%$ & $45 \%$ & $37 \%$ & $36 \%$ & $38 \%$ \\
\hline 522 Street Vendors & $0 \%$ & $0 \%$ & $0 \%$ & $0 \%$ & $0 \%$ & $0 \%$ \\
\hline 523 Fashion and Other Models & $0 \%$ & $0 \%$ & $0 \%$ & $0 \%$ & $0 \%$ & $0 \%$ \\
\hline 5 Service and Sales Workers & 15,840 & 4,431 & 8,997 & 291 & 29,307 & 267,645 \\
\hline
\end{tabular}

Source: Census of Population and Dwellings 2006, Statistics New Zealand.

Note: Occupations are coded according to NZSCO99 and are reported at the 3-digit level.

\section{Acknowledgements}

This paper was reviewed by Hillmare Schulze, Department of Labour.

\section{References}

Badkar, J. and Tuya, C. (2010) The Asian workforce: a critical part of New Zealand's current and future labour market. Department of Labour, Wellington.

Badkar, J., Callister, P. and Didham, R. (2008) The origin, family structure and labour supply of overseas born nurses. Paper presented at the LEW 13 / ALMRW conference, Wellington.
Badkar, J., Callister, P., Krishnan, V., Didham, R. and Bedford, R. (2007) Gender mobility and migration into New Zealand: A case study of Asian migration. Social Policy Journal, 32: 152-180.

Department of Labour (2009) Migration trends and outlook 2007/08. Department of Labour, Wellington.

Manning, R. and SriRamaratnam, R. (2010) Employment by skills in New Zealand and migrant's share in its recent growth: trans-Tasman and wider comparisons. Paper presented at the NZAE conference, Auckland. 